\title{
Physiological Effects of Human-Animal Positive Interaction in Dogs - Review of the Literature
}

\author{
Denisa POP*1), Alina S. RUSU ${ }^{2)}$, Vlad POP-VANCIA ${ }^{1)}$, Ionel PAPUC ${ }^{3)}$, Radu CONSTANTINESCU ${ }^{11}$, \\ Vioara MIRESAN*1) \\ ${ }^{1)}$ Department of Animal Science, University of Agricultural Sciences and Veterinary Medicine, Romania \\ ${ }^{2)}$ Department of Special Education, Babes-Bolyai University, Romania \\ ${ }^{3)}$ Department of Veterinary Medicine, University of Agricultural Sciences and Veterinary Medicine, \\ Romania \\ "Corresponding authors, email: denisa.pop@usamvcluj.ro,vmiresan@yahoo.com
}

Bulletin UASVM Animal Science and Biotechnologies 71(2) / 2014,

Print ISSN 1843-5262; Electronic ISSN 1843-536X

DOI:10.15835/buasvmcn-asb:10398

\begin{abstract}
Positive human-animal interactions (HAI) are known to increase the quality of life in both humans and dogs. Although there are several reviews on the benefits of HAI in humans, there are no reviews on the effects of positive HAI in dogs. Therefore, the aim of this paper is to provide a review of the articles indicating the physiological changes in dogs that correlate with welfare, during and after positive interactions with humans. The reviewed scientific papers were published between 2000 and 2014. HAI took place either in the laboratory context or in natural settings, such as Animal Assisted Therapy (AAT) locations or dog shelters. The dogs interacted either with their owners, with a familiar person or with an unfamiliar person. The measured physiological variables were the level of blood pressure, heart rate and the levels of several hormones. The studies indicated that positive HAI was usually associated with a significant decrease in blood pressure and in the levels of cortisol, as well as with a significant increase in the levels of b-endorphin, oxytocin, prolactin, phenylacetic acid and dopamine. Some studies had contradictory results, where the levels of cortisol were higher after interaction, suggesting there are other factors which may mediate/moderate the effects. The studies which also measured the physiological changes in humans reported positive correlations between the changes in dogs and the ones in humans.
\end{abstract}

Keywords: animal-assisted interventions, human-animal interaction, pet dogs, shelter dogs, therapy dogs, welfare

\section{INTRODUCTION}

The cooperation between humans and the ancestors of dogs is thought to have begun around 14 thousand years ago, when people were living in hunter-gatherer societies and dogs were helping them hunt (Serpell, 1995). Then, when people started to build homes and live in the same place, doing agriculture, dogs stayed and protected their shelters, again in exchange for food (Decun, 2004). To ensure the survival in the long term, new aspects of behavior have emerged in the context of human-dog evolutionary co-existence. As we can now see, dogs show a high sociability level in the interaction with humans, aspect that does not appear in wolves (Miklosi, 2007). This trait seems to be very useful nowadays, suggesting that humans might benefit from it in the form of companionship, having the opportunity for caring, for comfort and relaxation, for being altruistic, for being playful, for appreciating nature and others, all being possible while interacting with the dog (Holbrook et al., 2001). Vas et al. (2005) have noticed that this process is bidirectional and that dogs might have evolved the abilities to adjust their behavior and emotional responses in concordance with the humans', action called emotional synchronization (Miklosi, 2007).

The purpose of this review is to offer a physiological perspective on the positive humananimal interaction in different populations of dogs, in order to get a better understanding of 
their welfare-related indicators and needs in the context of human-animal interactions.

\section{CRITERIA FOR INCLUSION OF STUDIES IN THIS REVIEW}

In this review, we aimed to focus on the effects of positive HAI on physiological variables in the following categories of dogs: pet, shelter, therapy and working dogs. Positive HAI included: playing, talking to the dog, petting the dog, using positive reinforcement like treats and others (Tab. 1), in experimental settings or natural settings such as animal-assisted intervention places or dog shelters. The physiological changes related to human-dog interactions included: heart rate variability, heart rate, blood pressure and hormones which have been previously associated with wellbeing and stress reduction in different species. In the studies included in our review, the hormone concentrations have been measured from samples taken from plasma, but in the case of cortisol, in most of the studies, the cortisol was measured from saliva samples, due to the noninvasive nature of the method and to the significant correlations of the cortisol with the plasma levels in some species, including dogs (Vincent and Michell, 1992; Beerda et al., 1996).

The prime criterion for inclusion of studies in our review was the publication of the original research in a peer-reviewed scientific journal. Mainly Google Scholar was used for the article search. Search terms were: HAI, physiological changes in dogs, AAT, stress in dogs, dog welfare.

The second criterion for inclusion was a sample size of at least 5 subjects, so case reports with only one participant dog were excluded from our review (e.g. Piva et l., 2008).

EFFECTSOFHUMAN-ANIMALINTERACTION Psycho-physiological changes in dogs from animal shelters interacting with humans. Dog shelters are considered to not offer a natural environment for dogs in terms of optimal welfarerelated requirements. Problems like social isolation might appear (Hennessy et al., 1997), which represent a major stressor, because dogs are social animals (Hubrecht and Turner, 1998; Coppinger and Zuccotti, 1999). Improving social contact might be one solution for increasing the welfare of dogs (Wells and Hepper, 2000; Hennessy et al., 2002; Wells, 2004; Valsecchi et al., 2007;
Normando et al., 2009), besides the improvement of the housing conditions (Mertens and Unshelm, 1996).

We reviewed four studies which measured the physiological changes of the social contact with shelter dogs (human-dogs interactions). Physiological measurements included saliva or plasma cortisol, elevated cortisol being the most valuable indicator of poor welfare for dogs (Rooney et al., 2007). All three studies which followed shelter dogs socializing with people at the shelter grounds showed a reduction in cortisol (Bergamasco et al., 2010; Coppola et al., 2006; Shiverdecker et al., 2013), which suggests that dogs became less stressed after human contact. The fourth study (Hennessy et al., 2006) was a program designed for shelter dogs, that were moved to a prison to socialize with the inmates; the levels of cortisol did not change from pretest to posttest, but the authors concluded that dogs in shelters might suffer from a dysregulation of the hypothalamic-pituitary-adrenal axis which might change through socialization programs (Hennessy et al., 2006).

In the study made by Bergamasco et al. (2010), the study group was submitted to a behavioral intervention consisting in 20 minutes sessions of supplemental human interaction and positive reinforcement based educational skill training, occurring 3 days each week for a period of 8 weeks. The contact session included playing with the dog outside, walking on leash, grooming activities, playing inside with toys, obedience commands; treat rewards, and verbal and tactile contact. The sessions were conducted by the same female human handler. The results showed a decrease in the salivary cortisol levels in the experimental group and also changes in heart rate variability (HRV) between groups. HRV is an indicator for the non-invasive assessment of autonomic nervous system activity in response to psycho-physiological stress (Tiller et al., 1996). During physically or emotionally stressful events, a decreased HRV has been reported (Sgoifo et al., 1999, 2001).

The population in Bergamasco et al. study (2010) was long-term sheltered dogs (residents at the shelter for at least 7 months), but another study (Coppola et al., 2006) followed dogs in their first days at the shelter, suggesting that the third day may be the most stressful one for dogs housed 
in shelters because they have not yet begun to acclimate, they have to respond to consistently unpredictable surroundings and unlike day 2, they may have reached their tolerance level for novel, irritating stimuli. On day 3 , the contact animals had much lower cortisol levels than the no-contact animals. Animals in the contact group engaged in a human contact session on day 2; the session included playing with the dog outside, walking on leash, grooming activities, playing inside with toys, obedience commands, treat rewards, and verbal and tactile contact. Each session lasted an average of 45 minutes and was conducted by the same female human evaluator. If animals were still present in the shelter on days 3,4 and 9 subsequent saliva samples were collected. Animals in the nocontact group had higher cortisol levels on day 3 than any other day. The contact animals' cortisol levels remained at approximately the same level throughout the duration of the study (Coppola et al., 2006).

Shiverdecker et al. (2013) also followed dogs in their first days at the shelter, attempting to identify a human-interaction procedure that would reduce the cortisol response. To be practical for shelters to implement, a 30-minute procedure was chosen, which consisted in a design with three conditions, in which the dogs experienced either the passive presence of a human, a soothing petting procedure, or active play and training. This time, the cortisol levels were assessed from plasma samples. The results showed a reduction in plasma cortisol concentrations from pretest to posttest in all three conditions receiving human interaction, but not in control groups (staying alone in the room or in the cage).

In a socialization program for shelter dogs, Hennessy et al. (2006) examined: responsiveness to commands, behaviors in a novel and potentially threatening situation, plasma ACTH and cortisol concentrations in shelter dogs that either had experienced a 3-week socialization program including obedience training at a prison or had remained at the shelter for the same period of time (control dogs). Dogs receiving the socialization treatment at the prison remained with their individual handlers almost constantly. This involved staying in the handler's cell at night and during daytime periods when the handler chose or was required to remain in his cell. For approximately 10 hours each day, dogs and their handlers interacted with other prisoners and dogs in the common area of the housing unit, and frequently accompanied the handlers to other locations on the prison grounds. Whereas plasma cortisol levels did not vary from pretest to posttest in either group, ACTH levels unexpectedly increased with time in both groups. Moreover, cortisol and ACTH levels were significantly positively correlated with each other at the posttest, but not the pretest. These results provide evidence for positive behavioral outcomes of prison socialization programs for shelter dogs, as well as further support for the notion that shelter housing results in a dysregulation of the hypothalamic-pituitary-adrenal axis (Hennessy et al., 2006).

Psycho-physiological changes in pet dogs interacting with humans. In the studies where dogs interacted with their owners, the researchers wanted to see if there are other effects besides a reduction in cortisol. Odendaal (2000) was the first who tried to determine a physiological basis for affiliation behavior between humans and dogs, suggesting that if the physiological reactions are mutual, dogs would experience the same psychological benefits from these neurophysiological changes as humans (Odendaal \& Meintjes, 2003). The parameters chosen were b-endorphin, oxytocin, prolactin, b-phenylethylamine, dopamine, and cortisol. The blood samples were collected immediately after a decrease in the mean arterial blood pressure took place. Controls were baseline vs. after interaction values, dogs interacting with owners vs. unfamiliar people. The interaction consisted of talking softly, touching and stroking the dogs. The results showed a decrease in blood pressure in both dogs and humans, increased levels in the parameters correlated with wellbeing like b-endorphin, oxytocin, prolactin, phenylacetic acid (metabolite of b-phenylethylamine) and dopamine. The increase in oxytocin was higher in the experimental group where people interacted with their own dogs. Cortisol decreased significantly only in humans. One of the reasons cortisol levels had not decreased might be the novel environment in which the experiment took place. But an important finding is that a significant decrease in blood pressure and thus all the other physiological effects can be achieved between 5 
and 24 minutes of positive interaction (Odendaal $\&$ Meintjies, 2003).

Handlin et al. (2011, 2012) also obtained significant differences from pretest to posttest regarding oxytocin levels in both dogs and their owners, which positively interacted. There was a positive correlation between the dogs' and the owners' oxytocin levels. The cortisol levels were also measured, which decreased in humans, but increased in dogs, explaining that a rise in cortisol might not be connected to stress, but to the initiation of physical activity (Handlin et al., 2012).

Psycho-physiological changes in dogs participating in animal-assisted interventions (AAI). AAI is a term which includes both animalassisted therapy (AAT) and animal-assisted activities (AAA). As defined by the most recognized international organization in AAI domain, Pet Partners (formerly known as Delta Society) AAT is "a goal-directed intervention in which an animal that meets specific criteria is an integral part of the treatment process. AAT is directed and/or delivered by a health/human service professional with specialized expertise and within the scope of practice of his/her profession. Key features include specified goals and objectives for each individual and measured progress... AAA provides opportunities for motivational, educational, recreational, and/or therapeutic benefits to enhance quality of life. AAAs are delivered in a variety of environments by specially trained professionals, paraprofessionals and/or volunteers in association with animals that meet specific criteria. Key features include absence of specific treatment goals; volunteers and treatment providers are not required to take detailed notes; visit content is spontaneous (Pet Partners, n.d.).

Dogs are the most commonly used animals in AAI, as shown in a meta-analysis by Nimer and Lundahl (2007). The researchers explain that dogs have a greater chance of being effective compared with other animals, because they are domesticated, easily accessed and trained. AAIs result in health benefits for humans with improvements in blood pressure, heart rate, salivary immunoglobulin A levels and in depression, anxiety, perceived quality of health, and loneliness (Morrison, 2007) but for dogs the situation is a little different. Although there is positive interaction between the human and dog, the accent is being put mostly on the welfare of the humans (Haubenhofer and Kirchengast, 2007). That might be one of the reasons why studies which measured the physiological changes in dogs during the therapy sessions obtained mixed results. We reviewed five studies of physiological changes in dogs during AAI's. In the research done by Haubenhofer and Kirchengast $(2006,2007)$ the dogs participated in sessions which varied from 1 to 8 hours. Cortisol levels were significantly related to the length of session, with concentrations being higher in shorter sessions than in longer ones. Also, the dogs produced significantly higher levels of cortisol on days on which they did therapeutic work than on control days. They also reached higher cortisol concentrations during short sessions, the owners' records indicating that there was more time pressure during these sessions, with dogs often working without breaks and doing more intense work. On the other hand, long sessions were characterized by many breaks. Another variable related to physiological arousal was the number of therapeutic sessions done each week, with cortisol concentrations increasing significantly with the number of sessions. The authors claim that the stress may be detrimental to the dogs' health but it might also be excitement generated by their therapeutic activities, so more studies are needed to determine if the dogs perceive it as distress or eustress.

The study conducted by King et al. (2011) showed that working breaks do not really make a difference in therapy dogs. In the experimental group, the sessions included a "quiet-play" timeout session in the middle of the working shift which consisted of 2 minutes alone with the handler, allowing the dog to chew on a toy, being petted or being talked to or providing mental stimulation in the form of obedience commands. The handlers chose whatever option would best calm their dog during the time-out session. Control sessions did not include a "quiet-play" time-out session and the handler dog team worked the entire two-hour shift. There was no difference between groups regarding the levels of salivary cortisol concentrations (King et al., 2011).

Keeping the dogs in lead during the sessions or leaving them free makes a difference in their cortisol levels, as shown by Glenk et al. (2013) who obtained significant lower levels of salivary cortisol from the dogs kept off lead. But they didn't find significant differences in the post-session 
cortisol versus home baseline versus pre-session in neither of the groups. Furthermore, in another study made by Glenk et al. (2014) in which the dogs participated in five therapy sessions at the same place and with the same group of people, the cortisol levels decreased significantly in the 4th and 5th sessions, suggesting that dogs became more relaxed once the environment and the people became familiar.

Psycho-physiological changes in other types of assistance dogs interacting with humans. In one study comprised of working police dogs and border guard dogs, Horvath et al. (2008) investigated how would the dogs react to a playful situation, taking into consideration that their jobs do not consist of positive interaction with humans. The experimental protocol included situations such as playful struggle with the handler (tug-ofwar game), but also cooperative behaviors like the retrieval of the toy or giving the toy up to the handler. The salivary cortisol concentrations after the test were significantly higher than before the test in police dogs, while cortisol concentrations after the test were significantly lower than before the test in border guard dogs. The reason for this, as the authors explained, is that police dogs may have executed playful behavior as part of a training exercise, due to the behavior of the handlers, while border guard dogs may have played spontaneously with their handler. Indeed, the police officers used more control commands in the play situation, while border guards petted the dogs more often and generally showed more enthusiasm in the play situation. The analysis revealed that the policemen continually disciplined their dogs and used sound signals to gain their dogs' attention during play sessions, while border guards were more empathetic and enthusiastic, and also petted and praised their dogs more often. Accordingly, the disciplinary behavior of policemen resulted in higher cortisol concentrations in the case of police dogs, while the friendlier attitude and petting by the border guards, reduced cortisol concentrations in the case of border guard dogs (Horvath et al., 2008).

\section{DISCUSSION AND CONCLUSION}

It appears that dogs brought to animal shelters lack socialization and this lack is reflected at psyho-physiological levels. Thus, the studies reviewed here show that concentrations in the cortisol hormone, which is associated with stress, decreased once the dogs started to interact positively with humans. This effect took place in all dogs, both long-term sheltered ones (Bergamasco et al., 2010) and also in new arrivals (Coppola et al., 2006; Shiverdecker et al., 2013).

Because pet dogs usually get a lot of attention from their owners, some researchers wanted to see what other hormones are involved in the well being of animals (including the level of stress). Odendaal (2000; Odendaal and Lehmann, 2000; Odendaal \& Meintjes, 2003) have noticed that dogs interacting with their own owners (versus a stranger) had higher levels of oxytocin, a hormone that is known to promote attachment between individuals and stimulate social interactive behavior (Carter, 1998; Handlin et al., 2011; Handlin et al. 2012). Instead, levels of cortisol have not decreased by contrary in some of the studies they showed increased levels in the posttest condition. One reason may be that dogs were excited because of the novel environment. In humans, a decrease in the cortisol levels took place, but all the other concentrations of hormones correlated positively with the dogs': higher levels of b-endorphin, oxytocin, prolactin, phenylacetic acid and dopamine together with a reduction in blood pressure during the positive interaction, confirming that both humans and dogs benefit from it. AAI dogs, even if they interact positively with humans, may manifest signs of stress through high levels of cortisol because of the long working hours and intense work (Haubenhofer and Kirchengast, 2006; 2007), with the levels starting to decrease if the dogs are kept off lead (Glenk et al., 2013) and if they visit the same people at the same place (Glenk et al., 2014). Also, it seemed that short breaks of positive interaction with the handler were not sufficient to reduce the cortisol concentrations in AAI dogs (King et al., 2011). In other types of working dogs, like police and border guard dogs, it seems that the attitude of the handler plays an important role in their physiological changes associated with human-animal interactions (Horvath et al., 2008).

In conclusion, positive human-animal interaction appears to be related to changes in physiological variables in dogs, such as blood pressure, heart rate, hormones and other parameters correlated with well-being such as cortisol, oxytocin, b-endorphin, prolactin, phenylacetic acid and dopamine. However, there are still many other factors which might mediate/ moderate 
Tab. 1. Original studies included in the review

\begin{tabular}{|c|c|c|c|c|}
\hline Authors & Study & Population & $\mathrm{N}$ & Significant effects \\
\hline $\begin{array}{l}\text { Bergamasco } \\
\text { et al. }(2010)\end{array}$ & $\begin{array}{l}\text { Contact session with humans; } \\
\text { control group }\end{array}$ & $\begin{array}{c}\text { Long-term } \\
\text { sheltered dogs } \\
\text { (residents at the } \\
\text { shelter for at } \\
\text { least } 7 \text { months } \\
\text { and not more } \\
\text { than } 3 \text { years), } \\
\text { aged between } \\
18 \text { months and } 6 \\
\text { years }\end{array}$ & $\begin{array}{c}10 / \\
9\end{array}$ & $\begin{array}{l}\text { Differences in heart rate } \\
\text { variability between groups } \\
\text { and decreased salivary cortisol } \\
\text { levels in the experimental group }\end{array}$ \\
\hline
\end{tabular}

\begin{tabular}{|c|c|c|c|c|}
\hline $\begin{array}{l}\text { Coppola } \\
\text { et al. (2006) }\end{array}$ & $\begin{array}{l}\text { Contact session with humans } \\
\text { shortly after arrival; control } \\
\text { group }\end{array}$ & $\begin{array}{l}\text { Adult dogs in } \\
\text { their first days at } \\
\text { the animal shelter }\end{array}$ & $\begin{array}{c}68 / \\
62\end{array}$ & $\begin{array}{l}\text { Lower salivary cortisol levels } \\
\text { for the dogs who engaged in a } \\
\text { human contact session vs. no- } \\
\text { contact group }\end{array}$ \\
\hline $\begin{array}{l}\text { Shiverdecker } \\
\text { et al. (2013) }\end{array}$ & $\begin{array}{l}30 \text { min interaction procedure } \\
\text { with three conditions in which } \\
\text { the dogs experienced either the } \\
\text { passive presence of a human, a } \\
\text { soothing petting procedure, or } \\
\text { active play and training }\end{array}$ & $\begin{array}{l}\text { Adult dogs in } \\
\text { their first days at } \\
\text { the animal shelter }\end{array}$ & 79 & $\begin{array}{l}\text { Reduction in plasma cortisol } \\
\text { concentrations from pretest to } \\
\text { posttest in all three conditions } \\
\text { receiving human interaction, } \\
\text { but not in Isolation and Home } \\
\text { Cage conditions }\end{array}$ \\
\hline $\begin{array}{l}\text { Hennessy } \\
\text { et al. (2006) }\end{array}$ & $\begin{array}{l}3 \text { week prison socialisation } \\
\text { program for shelter dogs; dogs } \\
\text { who remained at the shelter as } \\
\text { control group }\end{array}$ & $\begin{array}{l}\text { Adult sheltered } \\
\text { dogs }\end{array}$ & 26 & $\begin{array}{l}\text { ACTH levels increased } \\
\text { significantly across the } 3 \\
\text { weeks of the study in both } \\
\text { groups, but not cortisol levels; } \\
\text { concentrations of ACTH and } \\
\text { cortisol correlated positively } \\
\text { by the time of the posttest }\end{array}$ \\
\hline $\begin{array}{l}\text { Handlin } \\
\text { et al. (2011) } \\
\text { Handlin } \\
\text { et al. (2012) }\end{array}$ & $\begin{array}{l}\text { Short-term interaction between } \\
\text { dogs and their owners: petting, } \\
\text { stroking and talking to the dog; } \\
\text { evaluation of their relationship } \\
\text { through the Monash Dog Owner } \\
\text { Relationship Scale- correlations } \\
\text { between owners' and the dogs' } \\
\text { hormone levels }\end{array}$ & $\begin{array}{c}\text { Male Labrador } \\
\text { dogs (older than } 1 \\
\text { year) }\end{array}$ & 10 & $\begin{array}{l}\text { Increased levels of oxytocin } \\
\text { and plasma cortisol, decreased } \\
\text { heart rate in dogs; increased } \\
\text { levels of oxytocin and decreased } \\
\text { levels of cortisol in owners; } \\
\text { significant positive correlation } \\
\text { between the dogs' and the } \\
\text { owners' oxytocin levels }\end{array}$ \\
\hline $\begin{array}{l}\text { Haubenhofer } \\
\text { and } \\
\text { Kirchengast } \\
(2006) \\
\text { Haubenhofer } \\
\text { and } \\
\text { Kirchengast } \\
(2007)\end{array}$ & $\begin{array}{l}\text { Therapeutic sessions in AAAs } \\
\text { and AATs; resting days as } \\
\text { control group; the patients } \\
\text { hugged, talked to the dogs and } \\
\text { played with them }\end{array}$ & $\begin{array}{l}\text { Dogs between } 3-9 \\
\text { years, working } \\
\text { with their owners }\end{array}$ & 18 & $\begin{array}{l}\text { Higher cortisol levels on } \\
\text { therapy days, in both dogs and } \\
\text { humans, especially on shorter } \\
\text { sessions (in which the dog } \\
\text { had to do more intense work); } \\
\text { salivary cortisol concentrations } \\
\text { increasing significantly with the } \\
\text { number of sessions done during } \\
\text { a week (without rest) }\end{array}$ \\
\hline
\end{tabular}




\begin{tabular}{|c|c|c|c|c|}
\hline $\begin{array}{l}\text { Odendaal } \\
\text { (2000) } \\
\text { Odendaal } \\
\text { \& Lehmann } \\
(2000) \\
\text { Odendaal } \\
\text { \& Meintjes } \\
(2003)\end{array}$ & $\begin{array}{l}\text { Dogs interacting with dog loving } \\
\text { humans and with their owners. } \\
\text { The humans were instructed to } \\
\text { talk softly, touch and stroke the } \\
\text { dogs, in a laboratory setting; } \\
\text { controls were baseline vs. } \\
\text { after interaction values, dog } \\
\text { with their owners vs. dogs } \\
\text { interacting with unfamiliar } \\
\text { people }\end{array}$ & $\begin{array}{c}\text { Well-tempered } \\
\text { dogs older than } 2 \\
\text { years }\end{array}$ & 18 & $\begin{array}{l}\text { Decrease in blood pressure } \\
\text { in both dogs and humans, } \\
\text { increased levels of b-endorphin, } \\
\text { oxytocin, prolactin, } \\
\text { phenylacetic acid (metabolite } \\
\text { of b-phenylethylamine) and } \\
\text { dopamine; the increase in } \\
\text { oxytocin was higher in the } \\
\text { experimental group where } \\
\text { people interacted with their } \\
\text { own dogs; cortisol decreased } \\
\text { significantly only in humans. }\end{array}$ \\
\hline $\begin{array}{l}\text { Glenk } \\
\text { et al. (2014) }\end{array}$ & $\begin{array}{l}\text { Dogs interacted with people } \\
\text { during } 5 \text { AAT sessions: the } \\
\text { humans petted them, talked to } \\
\text { them and played with them }\end{array}$ & $\begin{array}{l}\text { Therapy dogs } \\
\text { (with at least } \\
2 \text { years of } \\
\text { experience in } \\
\text { AAT) }\end{array}$ & 5 & $\begin{array}{l}\text { Lower levels of salivary cortisol } \\
\text { in the post-session during the } \\
4 \text { th and } 5^{\text {th }} \text { sessions }\end{array}$ \\
\hline $\begin{array}{l}\text { King } \\
\text { et al. (2011) }\end{array}$ & $\begin{array}{l}2 \text { min "quiet-play" time-out } \\
\text { session between the AAT } \\
\text { working shifts with their } \\
\text { handlers; no play between } \\
\text { sessions (at the same dogs) as } \\
\text { control }\end{array}$ & $\begin{array}{l}\text { Certified therapy } \\
\text { dogs }\end{array}$ & 27 & $\begin{array}{l}\text { The "quiet-play" time-out } \\
\text { sessions made no difference for } \\
\text { canine stress as measured } \\
\text { by salivary cortisol } \\
\text { concentration }\end{array}$ \\
\hline $\begin{array}{l}\text { Glenk } \\
\text { et al. (2013) }\end{array}$ & $\begin{array}{l}\text { Participation in AAIs, people } \\
\text { playing with the dogs, petting, } \\
\text { talking with, handling them and } \\
\text { giving them treats }\end{array}$ & $\begin{array}{l}\text { Certified therapy } \\
\text { dogs or dogs in } \\
\text { training, ages } \\
\text { between } 1,5 \text { and } \\
14 \text { years }\end{array}$ & 21 & $\begin{array}{l}\text { no significant changes in } \\
\text { salivary cortisol in post-session } \\
\text { vs. home baseline vs. pre- } \\
\text { session in neither of the groups } \\
\text { significant difference in cortisol } \\
\text { between dogs kept in lead } \\
\text { (either therapy dogs or training } \\
\text { dogs) vs. dogs who were free }\end{array}$ \\
\hline $\begin{array}{l}\text { Horvath } \\
\text { et al. (2008) }\end{array}$ & $\begin{array}{l}\text { Dogs played with their handler } \\
\text { for } 3 \text { min with a tug toy }\end{array}$ & $\begin{array}{l}\text { Working police } \\
\text { dogs (male } \\
\text { German Shepherd } \\
\text { Dogs) and border } \\
\text { guard dogs }\end{array}$ & 84 & $\begin{array}{l}\text { The salivary cortisol } \\
\text { concentrations after the test } \\
\text { were significantly higher than } \\
\text { before the test in police dogs, } \\
\text { while cortisol concentrations } \\
\text { after the test were significantly } \\
\text { lower than before the test in } \\
\text { border guard dogs }\end{array}$ \\
\hline
\end{tabular}

the results presented in the studies included in our review, such as: the environment, the degree of human-dog attachment, the attitudes of the human, the duration of human-dog interaction, and the degree of freedom given to the dog.

Acknowledgements. This study is part of the doctoral thesis of the PhD candidate Denisa Pop, under the co-supervision of Vioara Miresan (University of Agricultural Sciences and Veterinary Medicine Cluj-Napoca) and Alina S. Rusu (BabesBolyai University).

\section{REFERENCES}

1. Beerda B, Schilder MB, Janssen NS, \& Mol JA (1996). Te use of saliva cortisol, urinary cortisol and catecholamine measurements for a noninvasive assessment of stress responses in dogs. Hormones and Behavior, 30, 272-279.

2. Bergamasco L, Osella M, Savarino P, Larosa G, Ozella L, Manassero M, Badino P, et al. (2010). Heart rate variability and saliva cortisol assessment in shelter dog: Humananimal interaction effects. Applied Animal Behaviour Science, 125, 56-68.

3. Carter CS (1998). Neuroendocrine perspectives on social attachment and love. Psychoneuroendocrinology, 23, 779-818. 
4. Coppinger R, Zuccotti J. (1999). Kennel enrichment: exercise and socialization of dogs. J Appl Anim Welf Sci., 2, 281-96.

5. Coppola CL, Grandin T \& Enns RM (2006). Human interaction and cortisol: can human contact reduce stress for shelter dogs? Physiology \& behavior, 87, 537-41.

6. Decun M (2004). Etologia, bunăstarea si protectia animalelor. Ed. Mirton, Timisoara.

7. Glenk L, Kothgassner O, Stetina B, Palme R, Kepplinger B \& Baran H (2013). Therapy dogs' salivary cortisol levels vary during animal-assisted interventions. Animal Welfare, 22, 369-378.

8. Glenk L, Kothgassner 0, Stetina B, Palme R, Kepplinger B \& Baran H (2014). Salivary cortisol and behavior in therapy dogs during animal-assisted interventions: A pilot study. Journal of Veterinary Behavior, 9, 98-106.

9. Handlin L, Hydbring-Sandberg E, Nilsson A, Ejdebäck M, Jansson A \& Uvnäs-Moberg K (2011). Short-Term Interaction between Dogs and Their Owners: Effects on Oxytocin, Cortisol, Insulin and Heart Rate-An Exploratory Study. Anthrozoos: A Multidisciplinary Journal of The Interactions of People \& Animals, 24, 301-315.

10. Handlin L, Nilsson A, Ejdebäck M, Hydbring-Sandberg E \& Uvnäs-Moberg K (2012). Associations between the Psychological Characteristics of the Human-Dog Relationship and Oxytocin and Cortisol Levels. Anthrozoos: A Multidisciplinary Journal of The Interactions of People \& Animals, 25, 215-228.

11. Haubenhofer, D., \& Kirchengast, S. (2006). Physiological Arousal for Companion Dogs Working With Their Owners in Animal-Assisted Activities and Animal-Assisted Therapy. Journal of Applied Animal Welfare Science, 9, 165-172.

12. Haubenhofer D \& Kirchengast S (2007). "Dog Handlers" and Dogs' Emotional and Cortisol Secretion Responses Associated with Animal-Assisted Therapy Sess. Society \& Animals, 15,127-150.

13. Hennessy MB, Davis HN, Williams MT, Mellott C, Douglas CW (1997). Plasma cortisol levels of dogs at a county animal shelter. Physiol. Behav., 62, 485-490.

14. Hennessy MB, Voith VL, Hawke JL, Young TL, Centrone J, McDowell AL, Linden F, Davenport GM (2002). Effects of a program of human interaction and alterations in diet composition on activity of the hypothalamic-pituitaryadrenal axis in dogs housed in a public animal shelter. J. Am. Vet. Med. Assoc., 221, 65-71.

15. Hennessy M, Morris A \& Linden F (2006). Evaluation of the effects of a socialization program in a prison on behavior and pituitary-adrenal hormone levels of shelter dogs. Applied Animal Behaviour Science, 99, 157-171.

16. Holbrook M, Stephens Debra, Day Ellen, Holbrook Sarah, Strazar G (2001). A collective stereographic photo essay on key aspects of animal companionship: the truth about cats and dogs. Acad Market Sci Rev, 1, 1-17.

17. Horváth Z, Dóka A \& Miklósi A (2008). Affiliative and disciplinary behavior of human handlers during play with their dog affects cortisol concentrations in opposite directions. Hormones and behavior, 107-114.
18. Hubrecht RH, Turner DC (1998). Companion animal welfare in private and institutional settings. In: Wilson, C.C., Turner, D.C. (Eds.), Companion Animal in Human Health. Sage Publications, Thousand Oaks, CA, 267-289.

19. King C, Watters J \& Mungre S (2011). Effect of a timeout session with working animal-assisted therapy dogs. Journal of Veterinary Behavior: Clinical Applications and Research, 6, 232-238.

20. Mertens PA, Unshelm J (1996). The effects of single and group housing on the behavior of kennelled dogs in animal shelter. Anthrozoös, 9, 40-51.

21. Miklosi A (2007). Dog Behaviour, Evolution, and Cognition. Oxford University Press, NY.

22. Morrison M (2007). Health Benefits of Animal-Assisted Interventions. Complementary Health Practice Review, 12, 51-62.

23. Nimer Janelle, Lundahl B (2007). Animal-assisted therapy: a meta-analysis (Report). Anthrozoos, 20, 225-239.

24. Normando S, Corain L, Salvadoretti M, Meers L, Valsecchi $P$ (2009). Effects of an enchanced human interaction program on shelter dogs' behaviour analysed using a novel nonparametric test. Appl. Anim. Behav. Sci., 116, 211-219.

25. Odendaal JSJ (2000). Animal-assisted therapy -magic or medicine? Journal of Psychosomatic Research, 48, 27580.

26. Odendaal JSJ, Lehmann SMC (2000). The role of phenylethylamine during positive human-dog interaction. Acta Vet. Brno, 69, 183-188.

27. Odendaal JSJ, Meintjes RA (2003). Neurophysiological correlates of affliative behavior between humans and dogs. The Veterinary Journal, 165, 296-301.

28. Pet Partners (n.d.). About animal-assisted activities \& animal-assisted therapy. Available at http://www. petpartners.org/.

29. Piva E, Liverani V, Accorsi P, Sarli G \& Gandini G (2008). Welfare in a shelter dog rehomed with Alzheimer patients. Journal of Veterinary Behavior: Clinical Applic and Research, 3(2), 8794.

30. Rooney NJ, Gaines S, Bradshaw JWS (2007). Behavioural and glucocorticoid responses of dogs (Canis familiaris) to kennelling: investigating mitigation of stress by prior habituation. Physiol Behav, 92, 47-54.

31. Serpell, J. (1995). The Domestic Dog: Its Evolution, Behaviour and Interactions with People. Cambridge University Press, Cambridge.

32. Sgoifo A, Koolhaas JM, Musso E, De Boer SF (1999). Different sympathovagal modulation of heart rate during social and nonsocial stress episodes in wild-type rats. Physiol. Behav,. 67, 733-738.

33. Sgoifo A, Pozzato C, Costoli T, Manghi M, Stilli D, Ferrari PF, Ceresini G, Musso E (2001). Cardiac responses to intermittent social conflict in rats. Physiol. Behav., 73, 343-349.

34. Shiverdecker M, Schiml P \& Hennessy M (2013). Human interaction moderates plasma cortisol and behavioral responses of dogs to shelter housing. Physiology \& behavior, 109, 75-79. 
35. Tiller WA, McCraty R, Atkinson M (1996). Cardiac coherence: a new, noninvasive measure of autonomic nervous system order. Altern. Ther. Health Med., 2, 52-65.

36. Valsecchi P, Pattacini O, Beretta V, Bertozzi J, Zannoni S, Viggiani R, Accorsi PA (2007). Effects of a human social enrichment program on behaviour and welfare of sheltered dogs. J. Vet. Behav. Clin. Appl. Res., 2, 87-88.

37. Vas J, Topal J, Gacsi M, Miklosi A and Csanyi V (2005). A friend or an enemy? Dogs' reaction to an unfamiliar person showing behavioural cues of threat and friendliness at different times. Applied Animal Behaviour Science, 94, 99-115.
38. Vincent IC \& Michell AR (1992). Comparison of cortisol concentrations in saliva and plasma of dogs. Research in Veterinary Science, 53, 342-345.

39. Wells DL, Hepper PG (2000). The influence of environmental change on the behaviour of sheltered dogs. Appl. Anim. Behav. Sci., 68, 151-162.

40. Wells DL (2004). A review of environmental enrichment for kenneled dogs, Canis familiaris. Appl. Anim. Behav. Sci., 85, 307-317. 